\title{
SISTEM SOSIAL-BUDAYA DI INDONESIA
}

\section{Nurdien H. Kistanto}

\author{
Fakultas Sastra Universitas Diponegoro
}

\begin{abstract}
Human creature and culture together build a socio-cultural life, patterned and systematically referred to a socio-cultural system. Systematization through adjustments with the socio-cultural thoughts and practices in norms, ideas, values, aesthetics, tradition, all of which can be realized through cultural elements, at one time was the cultural content. Sociocultural systems can be understood as the bowl of developing cultural elements as the embodiment of cultural contents which are intertwined. Five Indonesian socio-cultural systems, which are formed by cultural background and experiences from period to period, can be considered as the fruits of civilization and nation experiences perpetually moving and growing.
\end{abstract}

Key words: culture, society, socio-cultural systems, Indonesia

\section{Pendahuluan}

Masyarakat dan kebudayaan, yang dapat disebut kehidupan sosial-budaya, merupakan pengertian-pengertian, konsep-konsep dan kategori-kategori yang dalam ilmu-ilmu sosial dan budaya seperti sosiolog, antropologi sosial dan antropologi budaya, ilmu politik dan pemerintahan, filsafat, psikologi, sejarah, ilmu susastra dan ilmu bahasa, sering dibahas. Dalam pembahasan, sistem sosial seringkali dipisahkan dari sistem budaya, padahal kedua pengertian tersebut tak dapat dengan tegas dipisah-pisahkan. Dalam kehidupan masyarakat, gejala-gejala sosial dan gejala-gejala budaya hampir selalu, atau bahkan selalu, saling berhubungan dan berpengaruh, sehingga gejala-gejala dan kebiasaan-kebiasaan sosial tidak bisa dipisahkan dari gejala-gejala dan kebiasaan-kebiasaan budaya, demikian pun sebaliknya. Bahkan, seringkali tidak mudah orang melihat suatu gejala atau peristiwa itu gejala atau peristiwa sosial atau budaya, sistem-sistem sosial tidak bisa dipisahkan secara tegas dari sistem-sistem budaya, sehingga persoalan konseptual mengenai sistem sosial dan sistem budaya lebih memadai apabila dilakukan dalam satuan pembahasan sehingga kita mengenal sistem-sistem sosial-budaya (socio-cultural systems). 
Tulisan ini membahas tentang masyarakat dan kebudayaan, yang membangun pengertian-pengertian dan konsep-konsep mengenai sistem sosial, sistem budaya dan sistem sosial-budaya, menuju pembahasan mengenai 5 (lima) sistem sosial-budaya yang dibangun dan terbentuk dalam masyarakat Indonesia yang dari zaman ke zaman berkembang dan dinamis.

\section{Masyarakat dan Kebudayaan}

Pembahasan mengenai masyarakat dan kebudayaan atau kebudayaan dan masyarakat merupakan pembahasan yang sering menimbulkan perdebatan, terutama dalam ilmu-ilmu tentang kemanusiaan, hubungan antar manusia-manusia dan hubungan antar manusiamasyarakat, beserta kebudayaannya, baik dalam sosiologi, antropologi sosial dan antropologi budaya maupun dalam bidang-bidang ilmu-ilmu sosio-humaniora lainnya, bahkan dalam biologi dan sistem ekologi. Keadaan demikian dapat disadari karena senantiasa terjadi interaksi, dialog, dan hubungan timbal-balik antara masyarakat dan kebudayaannya, atau kebudayaan dan masyarakatnya, yang berkesinambungan sesuai dengan karakteristik dan dinamikanya, sehingga berlangsung tesa dan antitesa yang selalu menghasilkan sintesa sementara. Selain itu juga karena terjadinya perubahan, transformasi terus-menerus dalam masyarakat dan dalam praktek-praktek kebudayaan, sehingga dari waktu ke waktu, dari zaman ke zaman, pemahaman, pengertian dan konsep mengenai masyarakat dan kebudayaan menjadi pembahasan yang mendapat perhatian. Menurut Tim Ingold,

'Society' and 'culture' are among the most contentious concepts of the human sciences. Sometimes treated as virtually synonymous, sometimes radically distinguished, their study has been maintained as the particular preserve of social and cultural anthropology, at the same time as it has been opened up by biologists to embrace almost the entire field of animal behaviour (Ingold, 1996).

Dalam membahas tentang kebudayaan dan masyarakat, sosiolog Anthony Giddens (1991: 31) menegaskan bahwa,

Culture consists of the values the members of a given group hold, the norms they follow, and the material goods they create. Values are abstract ideals, while norms are 
definite principles or rules which people are expected to observe. Norms represent the 'dos' and 'don'ts' of social life....

When we use the term in ordinary daily conversation, we often think of 'culture' as equivalent to the 'higher things of the mind' - art, literature, music and painting... the concept includes such activities, but also far more. Culture refers to the whole way of life of the members of a society. It includes how they dress, their marriage customs and family life, their patterns of work, religious ceremonies and leisure pursuits. It covers also the goods they create and which become meaningful for them - bows and arrows, ploughs, factories and machines, computers, books, dwellings.

'Culture' can be conceptually distinguished from 'society', but there are very close connections between these notions. 'Culture' concerns the way of life of the members of a given society - their habits and customs, together with the material goods they produce. 'Society' refers to the system of interrelationships which connects together the individuals who share a common culture. No culture could exist without a society. But, equally, no society could exist without culture. Without culture we would not be 'human' at all, in the sense in which we usually understand that term. We would have no language in which to express ourselves, no sense of self-consciousness, and our ability to think or reason would be severely limited...(Giddens, 1991: 31-32).

Unsur-unsur kebudayaan yang tampak, nyata dan kelihatan dapat berwujud materi atau benda yang dapat disentuh dan dirasakan oleh panca-indera manusia, sesungguhnya merupakan hasil dan perwujudan dari unsur-unsur kebudayaan manusia yang tak dapat disentuh dan tak dapat dirasakan oleh panca-indera manusia. Unsur-unsur kebudayaan yang bersifat kebendaan (tangibles, material goods) seperti bangunan, mesin, peralatan, pakaian dan hasil teknologi lainnya, seperti komputer, baik secara langsung maupun tidak langsung, merupakan hasil-hasil dari unsur-unsur kebudayaan manusia yang tak-tampak (intangibles, immaterials) seperti pemikiran, gagasan, angan-angan, citraan, yang berada di wilayah batin, mental-spiritual dan pengolahan pemikiran, atau penggunaan otak dan akal-budi manusia, yang berdampingan dengan nilai-nilai, norma-norma, dan etika, yang diwariskan dan dikembangkan oleh manusia melalui dan sangat melibatkan fungsi dan peran pewarisan, pendidikan, pengajaran, pembelajaran, pembiasaan, yang berkelanjutan dan saling berhubungan, berinteraksi, tarik-menarik, timbang-menimbang dengan latar-belakang dan lingkungan kehidupannya. 
Sehubungan dengan pembahasan mengenai masyarakat dan kebudayaan atau, sebaliknya, kebudayaan dan masyarakat, Dennis O’Neil dalam artikel berjudul "What is Culture" (2002-2006) menekankan bahwa,

Culture and society are not the same thing. While cultures are complexes of learned behavior patterns and perceptions, societies are groups of interacting organisms. People are not the only animals that have societies. Schools of fish, flocks of birds, and hives of bees are societies. In the case of humans, however, societies are groups of people who directly or indirectly interact with each other. People in human societies also generally perceive that their society is distinct from other societies in terms of shared traditions and expectations.

While human societies and cultures are not the same thing, they are inextricably connected because culture is created and transmitted to others in a society. Cultures are not the product of lone individuals. They are the continuously evolving products of people interacting with each other. Cultural patterns such as language and politics make no sense except in terms of the interaction of people. If you were the only human on earth, there would be no need for language or government.

Pengertian tentang masyarakat dan kebudayaan, dengan demikian, adalah berbeda. Pada satu pengertian, masyarakat saling berinteraksi, baik di dalam sistem sosialnya maupun di luar sistem sosialnya; dan pada pengertian lain dalam berinteraksi tersebut manusia dan masyarakat menciptakan, menyelenggarakan dan mengembangkan kebudayaan dalam suatu sistem budaya. Hubungan timbal-balik antara masyarakat dan kebudayaan inilah yang membentuk sistem sosial dan sistem budaya. Pembahasan mengenai sistem sosial dan sistem budaya menjadi lebih bermakna apabila dipahami dan disadari bahwa dalam kehidupan manusia terdapat begitu banyak dan beragamnya sistem sosial dan sistem budaya, yang dapat disatu-padukan dalam pembahasan mengenai sistem sosial-budaya atau sistem-sistem sosialbudaya (socio-cultural systems).

\section{Sistem Sosial dan Sistem Budaya: Sistem Sosial-Budaya}

Pembahasan mengenai sistem sosial dan sistem budaya sebagaimana disampaikan dengan demikian menghasilkan pengertian-pengertian dan konsep-konsep mengenai sistem sosial, sistem budaya, dan sistem sosial-budaya, yang dimaksudkan agar pembahasan tentang masalah-masalah sosial dan masalah-masalah budaya dilakukan secara terpadu, dengan memperhatikan bahwa kedua kelompok masalah tersebut selalu saling berkaitan dan tidak 
mudah dipisah-pisahkan, bahkan seringkali kabur mengenai mana yang sesungguhnya masalah sosial dan mana yang masalah budaya. Penekanan-penekanan dalam pembahasan mengenai konsep-konsep dan pengertian-pengertian tentang sosial dan budaya justru makin menegaskan bahwa pembahasan tentang masalah-masalah sosial tak terpisahkan dari masalah-masalah budaya, yang membangun konsep dan pengertian tentang sistem sosialbudaya (socio-cultural system).

\section{1. Sistem Sosial}

Para pembahas menyebut konsep dan pengertian sistem sosial lebih menekankan pada hubungan-hubungan yang berlangsung antar manusia dan manusia, manusia dan masyarakat, masyarakat dan masyarakat, yang hampir selalu atau bahkan selalu dalam kerangka suatu satuan atau organisasi, sebagai satuan bersistem yang senantiasa berinteraksi, yakni interaksi sosial - sehingga dapat disebutkan bahwa setiap (satuan) masyarakat adalah bersistem, yang kemudian dikenal dengan sistem sosial (social system), yaitu satuan masyarakat yang bersistem.

Sistem sosial dipahami sebagai "any, especially a relatively persistent, patterning of social relations across 'time-space,' understood as reproduced practices" (Giddens, 1984). Dalam pengertian umum demikian, suatu masyarakat atau organisasi sosial atau kelompok, di mana dan kapan pun ia berada, merupakan suatu sistem sosial, yang di dalamnya dapat mengandung subsistem sosial dan dalam pola sistematik yang sangat beragam. Dalam faham fungsionalisme (Parsons, 1951) sistem sosial merupakan sistem interaksi yang berlangsung antara 2 (dua) pelaku atau lebih, yang masing-masing mengandung fungsi dalam suatu satuan masyarakat.

Sistem sosial dapat dipahami sebagai suatu sistem atau pemolaan dari hubunganhubungan sosial yang terdapat dan berkembang dalam masyarakat tertentu, sebagai wahana 
fungsional dalam masyarakat tersebut. Dalam pengertian umum demikian, suatu masyarakat atau organisasi sosial atau kelompok, di mana dan kapan pun ia berada, merupakan suatu sistem sosial, yang di dalamnya dapat mengandung subsistem sosial dan dalam pola sistematik yang sangat beragam. Sebagai satuan masyarakat, sistem sosial merupakan sistem yang menjadi wadah bagi totalitas hubungan antara seorang manusia dan manusia lainnya, manusia dan kelompoknya atau kelompok lain, kelompok manusia dan kelompok manusia lainnya, untuk memenuhi hajat, mempertahankan dan mengembangkan hidupnya, sesuai fungsi masing-masing. Manusia dan kelompok-kelompok manusia tersebut masing-masing secara relatif memiliki batas dan ikatan kewilayahan dan mengembangkan (unsur-unsur) kebudayaannya, termasuk lembaga-lembaganya seperti organisasi-organisasi sosial beserta peraturan-peraturannya yang tertulis dan tak tertulis.

\section{2. Sistem Budaya}

Pembahasan tentang manusia dalam masyarakat dan sistem sosial tak dapat dilepaskan dari pembahasan tentang kebudayaannya, beserta unsur-unsur kebudayaannya, baik unsurunsur yang tampak, nyata, kelihatan atau berwujud (tangible elements) maupun unsur-unsur yang tak-tampak, tak-nyata, tak-kelihatan atau tak-berujud (intangible elements; intangibles). Sistem budaya merupakan sistem atau satuan yang merupakan hasil satuan kompleksitas yang diciptakan dan diselenggarakan oleh manusia dalam masyarakat, dalam memenuhi dan mengembangkan hajat hidupnya dan lingkungannya, yang bersifat kebendaan dan bukankebendaan, yang dilakukan manusia melalui pewarisan, pendidikan, pengajaran, dan pembiasaan, yang berkelanjutan.

Dalam sistem budaya yang kompleks berlangsung saling-hubungan antar unsur-unsur budaya, terjadi interaksi fungsional dan simbolik antara satu unsur budaya dan unsur budaya lainnya. Action theory (teori tindakan) Parsons (1951) bahkan memandang bahwa sistem- 
sistem tindakan berlaku terhadap tingkatan-tingkatan analisis yang berbeda, mulai dengan organisme tingkah-laku dan sampai bangunan sistem budaya (Parsons, 1951; Ritzer and Goodman, 2004). Dasaran teori sosiologi sistem tindakan (action system) (Parsons, 1951) adalah membangun teori umum tentang masyarakat yang disusun sebagai peraturan dalam model sibernetik (cybernetic model) yang mengedepankan 4 (empat) imperatif fungsional, yaitu adaptasi (adaptation), pencapaian cita-cita (goal attainment), integrasi (integration), dan pemeliharaan pola, atau contoh, atau teladan (pattern maintenace). Sedangkan hierarki sistem, mulai dari sistem yang paling lemah sampai sistem yang cakupannya paling luas, secara berurutan, meliputi (1) organisme tingkah-laku (behavioral organism), (2) sistem kepribadian (personality system), (3) sistem sosial (social system), dan sistem budaya (cultural system). Parsons (1951) memandang tingkatan-tingkatan demikian secara hierarkis, dengan masing-masing tingkatan yang lebih rendah menyediakan daya dorong (impetus) bagi tingkatan-tingkatan yang lebih tinggi, dengan tingkatan-tingkatan yang lebih tinggi mengendalikan tingkatan-tingkatan yang lebih rendah; sehingga dapat dikatakan bahwa organisme tingkah-laku dan sistem kepribadian merupakan pendorong bagi sistem sosial dan sistem budaya, sementara sistem budaya mengendalikan sistem sosial, sistem kepribadian, dan organisme tingkah-laku, karena dalam hierarki tindakan, sistem budaya merupakan sistem pengendali tertinggi dalam tindakan sosial (social action).

\section{3. Sistem Sosial-Budaya}

Masyarakat manusia memiliki warisan-warisan genetik yang berbeda dari jenis makhluk lainnya. Warisan-warisan genetik manusia memberikan kemampuan kepada manusia untuk mengembangkan warisan-warisan budaya yang sangat beragam, yang sejak semula meliputi dimensi-dimensi sosial dan budaya, yang kemudian membangun sistem

sosial-budaya, bagi kelangsungan dan pengembangan kehidupannya. Sehingga dapat 
dikatakan bahwa, sistem sosial-budaya merupakan sistem paduan dari sistem sosial dan sistem budaya sehingga menjadi suatu sistem kemasyarakatan yang meliputi hubunganhubungan sosial yang dengannya manusia dalam masyarakat menghasilkan dan mengembangkan unsur-unsur budaya, untuk memenuhi hajat-hajat sosial dan budaya suatu masyarakat dalam melangsungkan dan mengembangkan kehidupan sosial-budayanya. Pembahasan mengenai dinamika dan perkembangan sistem sosial-budaya, sangat berhubungan dengan keadaan wilayah dan kewilayahan sosial dan budaya, kependudukan, unsur-unsur kebudayaan, yang mengandung hasil-hasil kebendaan (material, tangible goods) dan pemikiran manusia dalam masyarakat, organisasi-organisasi sosial dan lembaga-lembaga sosial budaya, beserta latar-belakangnya.

Masyarakat yang kompleks meliputi sistem-sistem sosial-budaya yang kompleks yang menggabungkan faktor-faktor sosial dan budaya dengan berbagai tingkatan kontradiksi dan konsistensi (Archer, 2004). Dalam sistem sosial-budaya yang kompleks itu, penemuan dan pemberian fungsi terhadap makna di balik tindakan manusia, bersamaan dengan penafsiran simbol terhadap tindakan manusia dan kelompok manusia, merupakan langkah kemuliaan. Akan tetapi makna dan simbol tindakan manusia dalam sistem sosial-budaya terlalu beragam, sehingga membutuhkan konseptualisasi model-model dan kategori-kategori makna dan simbol tindakan manusia dalam sistem sosial dan sistem budaya. Konseptualisasi sistem sosial-budaya dalam suatu bangsa akan menyediakan peluang yang berharga bagi bangsa tersebut untuk melihat, menghargai dan menentukan langkah-langkah dan tindakan konkrit dan ideal sehingga bangsa tersebut lebih mudah memantapkan perjalanannya meraih cita-cita bersama. Konseptualisasi ini mengajukan sistem sosial-budaya di Indonesia yang terdiri dari 5 (lima) sistem sosial-budaya yang lahir dan berkembang dari sumber-sumber dan pengalaman bangsa Indonesia selama ratusan tahun. 


\section{Sistem Sosial-Budaya di Indonesia}

Indonesia dikenal luas sebagai bangsa dengan realitas sosial-budaya yang begitu majemuk. Hubungan sosial-budaya antar masyarakat di Indonesia merupakan produk sejarah yang panjang, yang dari zaman ke zaman mengalami perkenalan dan pergaulan dengan bangsa-bangsa, agama-agama, dan kebudayaan-kebudayaan dunia. Demikian juga, nasionalisme Indonesia, kebangsaan Indonesia pun terbentuk, terbangun dan teruji oleh sejarah panjang, dari hasil interaksi "bangsa Indonesia" dengan bangsa-bangsa, agamaagama, dan kebudayaan-kebudayaan dunia. Pengalaman ini membentuk nilai-nilai lama dan nilai-nilai baru dalam masyarakat Indonesia. Sebagian nilai-nilai lama hendak ditinggalkan atau diperbaharui, sedangkan nilai-nilai baru yang sesuai dengan kebutuhan dan perkembangan peradaban bangsa pada masa sekarang dan masa mendatang harus senantiasa dipahami, diwujudkan dan diuji dalam pergaulan sosial-budaya.

\subsection{Kemajemukan dan Sistem Budaya}

Dengan hampir 14.000 (empat belas ribu) pulau, Indonesia merupakan kepulauan yang terbesar, seluas hampir 2 (dua) juta kilometer persegi, dan sepanjang dari ujung barat (Sabang di P. Weh) ke ujung timur (Merauke di Irian Jaya) sekitar 5.000 (lima ribu) km, yang dihuni oleh hampir 240 (dua ratus empat puluh juta) juta jiwa (terbesar kelima setelah Cina, India, AS, Rusia); dan dengan 5 (lima) pulau besar (Jawa, Sumatra, Kalimantan, Sulawesi dan Irian), Jawa merupakan pulau terpadat dan Irian Jaya terjarang penduduknya. Dengan sekitar 400 (empat ratus) suku dan kelompok etnik, sebanyak 726 (tujuh ratus dua puluh enam) bahasa daerah, yang sebagian punah atau hampir punah, selain bahasa Indonesia sebagai karya budaya bangsa yang memayungi bangsa dan mempermudah komunikasi antar warga bangsa, agama-agama dan unsur-unsur kebudayaan besar hidup dan berkembang dalam masyarakat bangsa dan komunitas-komunitas yang plural. 
Kemajemukan ini menyebabkan para ahli kebudayaan tidak mudah menentukan apa yang disebut kebudayaan nasional. Namun demikian, secara garis besar, Melalatoa (1997) mengajukan 3 (tiga) macam kebudayaan, atau sub-kebudayaan, dalam masyarakat Indonesia, sebagai berikut.

(1) Kebudayaan nasional Indonesia yang berlandaskan Pancasila dan UUD 45;

(2) kebudayaan suku-suku bangsa; dan

(3) kebudayaan umum lokal sebagai wadah yang mengakomodasi lestarinya perbedaanperbedaan identitas suku bangsa serta masyarakat-masyarakat yang saling berbeda kebudayaannya yang hidup dalam satu wilayah, misalnya pasar atau kota (Melalatoa, 1997: $6)$.

Sementara itu, Harsya W. Bachtiar (1985: 1-17) menyebut berkembangnya 4 (empat) sistem budaya di Indonesia, sebagai berikut.

(1). Sistem budaya etnik, yang berasal dari bermacam-macam etnik yang masingmasing memiliki wilayah budaya (18 masyarakat etnik, atau lebih); (2) sistem budaya agamaagama besar, yang bersumber dari praktek agama-agama Hindu, Budha, Islam, Kristen, dan Katolik; (3) sistem budaya Indonesia: bahasa Indonesia (dari Melayu), nama Indonesia, Pancasila dan UUD-RI; dan (4) sistem budaya asing yang bersumber dari India, Belanda, Arab/Timur Tengah, Cina, Amerika, Jepang, dan sebagainya.

\section{2. Sistem Sosial-Budaya di Indonesia}

Dengan latar-belakang dan pengalaman sosial-budaya yang begitu majemuk, meninjau gagasan-gagasan tentang sistem sosial-budaya, dalam masyarakat-bangsa Indonesia terdapat sistem-sistem sosial-budaya dan/atau subsistem-subsistem sosial-budaya, sebagai berikut.

\section{2. 1. Sistem Sosial-Budaya Nasional Indonesia}

Sistem sosial-budaya nasional Indonesia merupakan sistem masyarakat-bangsa yang menghasilkan, berlandaskan dan mewadahi (1) Pancasila sebagai Dasar Negara, dengan (2) 
Undang-Undang Dasar '45 sebagai Dasar Hukum, (3) nama Indonesia, sebagai nama bangsa dan negara, (4) bahasa Indonesia, sebagai bahasa nasional, yang semuanya menempati dan mengisi (5) Negara Kesatuan Republik Indonesia (NKRI), dalam bingkai (6) Garuda Pancasila, yang dilengkapi (7) semboyan Bhinneka Tunggal Ika, sebagai karya-karya budaya nasional yang memayungi dan mempersatukan masyarakat-bangsa Indonesia.

Bahan-bahan bagi hasil karya budaya berupa sistem sosial-budaya nasional Indonesia tersebut sudah ada dan dipraktekkan dalam kegiatan masyarakat dari zaman ke zaman, selama berabad-abad, dalam wilayah-wilayah yang sekarang menjadi Indonesia.

\section{2. 2. Sistem Sosial-Budaya Suku Bangsa dan Etnik Bangsa}

Sistem atau sub-sistem sosial-budaya suku bangsa dan kelompok etnik bangsa merupakan sub-subbudaya yang hidup di daerah-daerah dan wilayah-wilayah geografis Indonesia yang terbentuk secara turun-temurun dengan satuan-satuan subbudaya yang terbentuk sejak jauh sebelum kelahiran masyarakat-bangsa dalam negara Indonesia. Satuansatuan ini terdiri dari bermacam-macam suku dan etnik yang masing-masing memiliki daerah atau wilayah budaya atau sub-budaya, dengan masyarakat kesukuan dan etnik. Satuan-satuan itu bukan berasal dari bangsa seperti yang terjadi di Amerika Serikat, misalnya, orang-orang atau bangsa Inggris atau Jerman, atau Afrika Selatan, atau Amerika Latin (Chicano), atau Jepang dan Cina yang membentuk sub-subbudaya di Amerika Serikat, melainkan rumpunrumpun kesukuan dan etnik bangsa yang sejak lama, secara turun-temurun, menetap di wilayah yang kemudian disepakati disebut Indonesia.

\section{2. 3. Sistem Sosial-Budaya Agama}

Sistem sosial-budaya agama terbentuk dengan sumber-sumber dari ajaran-ajaran dan praktek agama-agama besar yang selama berabad-abad datang, tumbuh dan berkembang di wilayah Indonesia, yakni Hindu, Budha, Islam, Kristen dan Katolik, serta Kong $\mathrm{Hu} \mathrm{Cu}$. Selain itu, di daerah-daerah dan wilayah-wilayah budaya, berkembang pula praktek ajaran 
moral dan spiritual dari religi kesukuan dan etnik, dan penghayatan kepercayaan kepada Tuhan Yang Maha Esa, yang kelompok pelakunya disebut Himpunan Penghayat Kepercayaan (HPK), terutama di Jawa Barat, Jawa Tengah dan Jawa Timur.

\section{2. 4. Sistem Sosial-Budaya Asing}

Sistem sosial-budaya asing berasal dan terbentuk dari unsur-unsur budaya asing, seperti India, Melayu, Belanda, Arab dan Timur Tengah, Cina, Amerika Serikat, Jepang, Korea, dan sebagainya. Oleh masyarakat Indonesia, secara kreatif unsur-unsur budaya ini disaring, disesuaikan, dirombak, dipadukan, dan dikawinkan, meskipun ada yang dikenakan begitu saja. Unsur-unsur budaya dalam sistem sosial-budaya asing ini di satu pihak dapat dipandang memperkaya unsur-unsur budaya nasional dan daerah, yang acapkali menghasilkan percampuran unsur-unsur budaya baru yang unik dan diminati masyarakat; di lain pihak dipandang sebagai unsur-unsur budaya yang menjajah, mendominasi dan menggeser unsurunsur budaya daerah.

\section{2. 5. Sistem Sosial-Budaya Campuran}

Sistem sosial-budaya campuran merupakan tanggapan masyarakat terhadap masuknya unsur-unsur budaya lain, yang diterima dan dimanfaatkan untuk memperkaya unsur-unsur budaya yang dianggap asli, atau sudah hadir sejak lama sehingga percampuran antar unsurunsur budaya dapat terjadi. Sistem budaya campuran lazim terjadi dalam unsur-unsur budaya "sistem religi dan upacara keagamaan," misalnya dengan praktek sinkretisme dalam beragama; "bahasa," dengan menggunakan kata-kata dan ujaran-ujaran campuran dengan istilah dan kata-kata dari bahasa asing dalam komunikasi tulisan maupun lisan; "kesenian," merupakan satu unsur budaya yang mudah bercampuran, antara unsur-unsur yang ada dalam dirinya dengan unsur-unsur lain yang masuk, musik ndang-dut Rhoma Irama yang berhasil meraih hati penggemar dalam jumlah besar merupakan contoh fenomenal yang menarik; "sistem dan organisasi kemasyarakatan" yang dapat terjadi misalnya dalam praktek politik 
berdemokrasi beserta implementasi dan pelaksanaannya; dan "sistem mata pencaharian hidup" yang sangat mempengaruhi cara, strategi, dan kebijakan serta praktek dalam kebijakan dan praktek ekonomi masyarakat-bangsa.

\section{Simpulan}

Manusia dan kebudayaan bersama-sama membangun kehidupan sosial-budaya, yang terpola dan secara sistematis disebut sistem sosial-budaya. Sistematisasi sosial-budaya terjadi melalui penyesuaian bersama dalam norma-norma, ide-ide, nilai-nilai, estetika, tradisi, yang semuanya dapat diwujudkan melalui unsur-unsur kebudayaan, yang sekaligus merupakan isi kebudayaan.

Kebudayaan hidup di dalam sistem sosial-budaya yang mengembangkannya, yang merupakan wadah dinamikka dan pengembangan unsur-unsur budaya sebagai perwujudan dari isi kebudayaan yang senantiasa saling berhubungan dan berjalinan. Lima sistem sosialbudaya yang hidup dan mewadahi hajat hidup masyarakat Indonesia terbentuk oleh latarbelakang dan pengalaman kebudayaan, dari zaman ke zaman sehingga merupakan buah peradaban dan pengalaman bangsa yang senantiasa bergerak dan berkembang.

Sistem-sistem sosial-budaya di Indonesia memerlukan pembahasan lebih lanjut dan terperinci dengan kepentingan mengidentifikasi sistem sosial-budaya yang berkembang dan merencanakan strategi pembangunan sosial-budaya yang bermanfaat bagi penyelenggaraan kehidupan sosial-budaya yang berbasis latar-belakang sosial-budaya, realitas sosial-budaya dan dinamika sosial-budaya yang senantiasa bergerak dan berkembang. 


\section{Daftar Pustaka}

Alexander, Paul. Ed. 1989. Creating Indonesian Cultures. Sydney: Oceania Publications.

Alfian. Ed. 1985. Persepsi Masyarakat tentang Kebudayaan. Jakarta: Gramedia.

Archer, Margaret S. 2004. Culture and Agency: The Place of Culture in Social Theory, Revised Edition. New York and Cambridge: Cambridge University Press.

Bachtiar, Harsya W., Mattulada, Haryati Soebadio. 1985. Budaya dan Manusia Indonesia. Yogyakarta: Hanindita.

Benedict, Ruth. 1959. Patterns of Culture. Boston: Houghton Mifflin Company.

Birket-Smith, Kaj. 1965. The Paths of Culture. Madison and Milwaukee: The University of Wisconsin Press.

Burrowes, Carl Patrick. 1996. From Functionalism to Cultural Studies: Manifest Ruptures and Latent Continuities, Communication Theory, 6 (1):88-103.

Geertz, Clifford. 1960. 1976. The Religion of Java. Chicago and London: The University of Chicago Press.

1966. "Religion as a Cultural System," in M. Banton (ed.), Anthropological Approaches to the Study of Religion. New York: Praeger, pp. 1-46.

1973. The Interpretation of Cultures. New York: Basic Books.

New York: Basic Books.

1983. Local Knowledge - Further Essays in Interpretive Anthropology.

1995. After the Fact - Two Countries, Four Decades, One Anthropologist.

Cambridge, Massachusetts: Harvard University Press.

Giddens, Anthony. 1984. The Constitution of Society. Cambridge: Polity Press. 1990. Sociology. Cambridge: Polity Press.

Harris, Marvin. 1968. The Rise of Anthropological Theory. New York: Thomas Y. Crowell.

Random House.

1974. Cows, Pigs, Wars and Witches: The Riddles of Culture. New York:

1979. Cultural Materialism: The Struggle for a Science of Culture. New

York: Random House. 
Publishers.

Ingold, Tim. 1996. "Social relations, human ecology, and the evolution of culture: an exploration of concepts and definitions," in Andrew Lock \& Charles R. Peters. Eds. Handbook of Human Symbolic Evolution. Oxford: Clarendon Press.

Jary, David \& Julia Jary. 1991. Collins Dictionary of Sociology. Glasgow: HarperCollins.

Koentjaraningrat (Redaksi). 1971. 1993. Manusia dan Kebudayaan di Indonesia. Jakarta: Djambatan.

Gramedia.

1974. 1984a. Kebudayaan, Mentalitas dan Pembangunan. Jakarta: 1984b. Kebudayaan Jawa. Jakarta: Balai Pustaka.

Lim, Soo Kyung. May 1998. "Subdisciplines: Cultural Materialism.” Paper designed by Cierra Olivia Tho, facilitated by Richard Wilk, Anthropology Department, Indiana University Bloomington.

Lock, Andrew \& Charles R. Peters. Eds. 1996. Handbook of Human Symbolic Evolution. Oxford: Clarendon Press.

Lockwood, David. 1964. "Social Integration and System Integration," in G. Zollschan and W. Hirsch (eds.), Explorations in Social Change. Boston: Houghton Mifflin.

Malinowski, Bronislaw. 1960. A Scientific Theory of Culture and Other Essays. New York: Oxford University Press.

Melalatoa, M. Junus (Penyunting). 1997. Sistem Budaya Indonesia. Jakarta: FISIP UI dengan PT Pamator.

Montagu, M. F. Ashley. Ed. 1968. Culture: Man's Adaptive Dimension. London: Oxford University Press.

Mulder, Niels. 1989. Individual and Society in Java - A Cultural Analysis. Yogyakarta: Gadjah Mada University Press.

Murphy, Robert F. 1979. An Overture to Social Anthropology. Englewood Cliffs, New Jersey: Prentice-Hall.

O’Neil, Dennis. Copyright 2002-2006. "What is Culture." All rights reserved, last updated on Friday, May 26, 2006.

Parsons, Talcott. 1951. The Social System. London: Routledge \& Kegan Paul. 
Pemberton, John. 1994. On the Subject of "Java". Ithaca and London: Cornell University Press.

Peursen, C. A. Van. 1976. Strategi Kebudayaan. Jakarta: BPK Gunung Mulia; Yogyakarta: Kanisius.

Quilici, Folco. 1972. 1975. Primitive Societies. London: Collins. New York: Franklin Watts.

Ritzer, George and Douglas J. Goodman. 2004. "Structural Functionalism, Neofunctionalism, and Conflict Theory," in Sociological Theory, sixth edition. McGraw-Hill.

White, Leslie A. with Beth Dillingham. 1973. The Concept of Culture. Minneapolis, Minnesota: Burgess.

"Cultural System" http://en.wikipedia.org/w/index.php?title=Cultural_system\&oldid= $\underline{425205210 .}$.

"Social System" http://en.wikipedia.org/w/index.php?title=Social_system \&oldid= $\underline{510408398 .}$. 